\title{
Tempo livre e humanização: dúvidas e esperanças ante as novas possibilidades de lazer
}

\author{
Suzana Guerra Albornoz \\ Departamento de Ciências Humanas da Universidade de Santa Cruz do Sul (UNISC)
}

\begin{abstract}
Movido pela esperança despertada pela expansão do "tempo livre" no modo de vida contemporâneo, este texto indaga o significado de humano e humanização, rememorando brevemente a história desses conceitos e referindo-se a fragmentos da filosofia da utopia de Ernst Bloch em O princípio esperança, onde o tempo livre de trabalho é visto sob um olhar crítico, mas também como oportunidade para o aperfeiçoamento humano.
\end{abstract}

Palavras-chave: Tempo livre, Humanização, Ernst Bloch, Utopia, Cultura, Arte.

Leisure and humanization: doubts and hopes in the face of new possibilities for leisure

Moved by the hope awaked by the expansion of "free-time" in the contemporary way of life, this text questions about the meaning of human and humanization, remembering briefly the history of these concepts and referring to fragments of the philosophy of utopia of Ernst Bloch in The principle of hope, where the time free of work is seen under a critical light, but also as an opportunity for human improvement.

Keywords: Free time, Humanization, Ernst Bloch, Utopia, Culture, Art.

\section{Introdução}

\begin{abstract}
A era do trabalho estará no fim? Assim se pode pensar ao ver crescer cada vez mais o "tempo livre", entendido como tempo livre do trabalho, que pode ser utilizado para apenas repor as forças materiais para a volta ao trabalho, ou ser entregue ao dolce far niente, o que já é algo mais, mas que também, além disso, pode transformar-se em tempo de lazer, esportivo ou artístico e cultural, ou ser posto a serviço de atividades criativas, se não propriamente produtivas, isto é, dedicar-se ao pensamento, à arte, ao estudo, como indicado na expressão "ócio criativo"; finalmente, pode ser dado à ação comunitária ou política. A realidade, por outro lado, ainda parece negar esse anúncio do novo tempo livre, da libertação do excesso de esforço na produção, uma vez que se acumulam os ônus psicológicos e ainda se evidenciam novos tipos de sacrifícios físicos também ligados ao trabalho predominantemente intelectual ou imaterial. Por isso, algumas interpretações do momento repercutem como antecipações extemporâneas e parecem afins com as utopias, pois não parecem descrever a realidade efetiva e o que anunciam ainda não se tornou realidade em grande parte do mundo atual. Todavia, a visão que pode parecer utópica, do ócio criativo ou do lazer cultural que trabalha no sentido do desenvolvimento humano, situa-se confortavelmente no plano da possibilidade, naquela franja onde se elabora o real possível, onde urdem sua teia as utopias entendidas em seu sentido positivo, tal qual se pode encontrar na concepção de utopia concreta exposta na obra de Ernst Bloch.
\end{abstract}


Esse sonho do mundo da liberdade, da superação da exploração do trabalho, onde o trabalho vivo se liberta e o trabalhador pode tornar-se ao mesmo tempo camponês, político e filósofo, se não é inteiramente realidade ou apresenta-se como possibilidade restrita apenas a uma parte privilegiada da humanidade, tem sido a inspiração básica da monumental construção crítica do capitalismo, do marxismo até a chamada teoria crítica ligada à Escola de Frankfurt, e já se encontrava nos ensaios filosóficos do jovem Marx sobre a questão do trabalho. Na continuidade da reflexão marxista, Paul Lafargue, de modo muito próprio, chamou a atenção para o fato de haver a ideologia do trabalho conquistado a classe operária, quando se impôs como ética geral predominante na sociedade moderna, segundo os interesses do sistema de produção. Nestes tempos de mudança do capitalismo tardio, quando a alta automação provocada pelas sofisticadas tecnologias exige menos tempo e menos esforço físico para a produção necessária, é preciso revisar o que as reflexões críticas nos ensinam sobre esse outro lado da questão do valor do trabalho e da vita activa na modernidade, quando se inverteu a valoração tradicional antiga e medieval, na qual o ócio ocupava a melhor parte, como bem assinalava Hannah Arendt em seus estudos sobre a evolução da atividade produtiva na perspectiva da condição humana.

A maioria dos homens e mulheres de hoje, no entanto, rejeitam e temem o horizonte de um mundo em que diminui a necessidade de trabalho, porque isso significa diminuição do emprego e, embora se vislumbre a possibilidade de superação do esforço na produção industrial, sente-se a ameaça do desemprego, consequentemente, a sombra da dependência e, ainda mais, da falta de recursos para a sobrevivência digna. Nesta situação complexa, os operários reclamam por trabalho, que hoje é visto, ainda pela maioria das pessoas, nas mais diversas situações sociais, como centro e razão do sentido da vida e da coesão social. Tal desencontro entre a condição objetiva e o sonho mais antigo apresenta-se como um desafio ao pensamento dos humanistas, tanto para a crítica da ideologia do trabalho como para a exploração imaginária das possibilidades abertas pelo novo tempo livre, facilitado pela invenção tecnológica.

Ao mesmo tempo, percebe-se que o âmbito do lazer, na sociedade globalizada do capitalismo tardio, transformou-se em indústria, de um lado, fonte de trabalho, e de outro, de alienação ideológica e, assim, as respostas da moral e do humanismo precisam ser repensadas em relação com o lazer. Desse modo, os contraditórios problemas trazidos pelas novas situações provocam muito especialmente a filosofia prática e a reflexão sobre a educação, que talvez lhes possam oferecer respostas recebidas de sua tradição, mas deverão inventar novas respostas, com os recursos da criatividade própria da experiência da humanidade.

\section{Um pouco da história do conceito}

Suponho seja esclarecedor, para avançar na reflexão, começar por procurar entender melhor o que significa humano e humanização, com o qual se gostaria de ver marcado o lazer e a vivência da cultura no tempo livre que se abre com o desenvolvimento tecnológico; e para tanto, parece-me proveitoso recorrer à história do conceito, por não ser óbvio o que se diz ao usar a palavra humanização. A escolha do começo de esclarecimento de um conceito pela sua história já afirma a tese de que os conceitos são suscetíveis a mudanças, portanto, não possuem significação absoluta e permanente e estão submetidos à dimensão do tempo, de modo que se o homem e sua realidade, que dá consistência empírica ao conceito, é um ser suscetível a mudanças, nessas se inclui também o conceito que os homens se fazem do ser humano. Para possibilitar a revisão resumida da história do conceito, tomei como guia especialmente o verbete Mensch, do Historisches Wörterbuch der Philosophie, apresentado pelo notável grupo de autores alemães coordenado pela equipe junto a Joachim Ritter. $O$ reconhecimento da 
evolução histórica dos conceitos, contudo, não quer dizer que não se considere a existência de nenhuma qualidade permanente ligada ao que se possa chamar de humano, nem que o humano seja um conceito que mude constantemente. Há algo entre o ser e o conceito que, apesar de todas as mudanças, parece permanecer, pelo menos parece ser algo que vale a pena tentar guardar ou fazer acontecer.

Entre os estudiosos das diversas áreas das ciências humanas, parece ser consenso que o homem é o ser que tem consciência de si e, pelo menos, busca compreender-se ao ter consciência de si, como indivíduo e como espécie. Segundo a conceituação mais aceita nos estudos antropológicos, o ser humano se destaca dos demais seres vivos e também dos outros animais por sua capacidade de consciência e compreensão, e por sua capacidade de simbolização. Essa maneira de ser do ser humano, ainda que sujeita a variadas denominações que, cada uma, denota algo diferente, pode ser dita como consciência de si ou espírito, mente ou razão, sendo esta a principal característica ressaltada em sua natureza, ou seja, na humanidade, desde o começo da construção reflexiva dos seres humanos que pensam a respeito de si mesmos, e nessa linha de reflexão, muitas vezes reduziu-se o sujeito humano ao sujeito do conhecimento.

Por outro lado, uma compreensão moralizante também acarretou ambiguidades e enganos sobre o ser dos homens; nem sempre foi considerado o fenômeno humano em todas as suas dimensões e realidades, o que significa negar ou esquecer suas possibilidades reais. E porque a vida humana, pela falta de determinação estrita, instintiva, do comportamento, busca regular-se através de normas éticas, a descrição do humano frequentemente se transforma na projeção da imagem do que ele deva ou desejaria ser. Portanto, para entender melhor os limites do que é o homem, que nos pode esclarecer sobre humanizar e humanização, isto que nos concerne na prática de educadores, deve ser de ajuda consultar, embora de modo breve, de passagem, o que na história do espírito, das religiões, da cultura, da filosofia mesmo, tem sido pensado sobre o ser humano, ou seja, o que os homens têm pensado e dito sobre si mesmos.

Considerando-se os antigos, não é fácil entender o que seja "o homem", pois não foi óbvio o que se pensou como sendo esse ser nos primórdios do pensamento ocidental. Em algumas línguas, homem inclui alguns outros animais; em outras, indica o clã ou a tribo, e mesmo na Grécia, ànthropos não se distinguiu desde sempre da natureza, e os filósofos jônicos tentaram situar o ser humano na natureza e no cosmos. No século de ouro da filosofia grega e na Escola de Atenas, o discípulo esquecido de Sócrates, Isócrates apelava aos atenienses para se tornarem fortes no discurso através da educação, pois os humanos se diferenciam dos outros animais, sobretudo, pelo uso e a arte da palavra, ou do pensamento que gera a palavra. Assim nos aproximamos do conceito que se estabeleceria no âmago de nossa herança cultural, contudo, a concepção antropológica que predominou na filosofia tem sua maior dívida para com Platão que, no que se refere à sua concepção de homem, sofreu, por sua vez, a influência das doutrinas órficas e pitagóricas. Se a existência histórica do orfismo grego não pode ser estabelecida com exatidão, restam até hoje, em nossa cultura ocidental, sobras dos mitos órficos em relação à origem da natureza e da natureza humana, sendo ainda presente a visão do homem como ser duplo, no qual a alma se encontra aprisionada no corpo por causa de uma culpa originária, sendo o corpo a prisão da alma. As sobras de compreensões míticas órficas contidas no pensamento do primeiro filósofo que voltou o pensamento sobre o homem, que tanto influenciaria a forma da religião cristã que tem predominado no ocidente, deixam ainda sua impressão forte e lançam sua luz e sua sombra sobre o conceito de humano até nossos dias. Pela visão platônica, o ser humano é uma natureza dupla, é aquele que deve servir o seu corpo e como tal não é ele mesmo corpo, mas algo distinto, a alma. Mesmo a alma na visão platônica não é uma unidade homogênea, logo, o que é próprio do homem, o seu caráter específico, seria apenas parte da alma, a alma racional.

Outra duplicidade em torno do conceito do ser humano é a visão antiga de que o homem seria uma espécie de intermediário entre o animal e a divindade, entre o anjo e a besta. 
Se o homem não pode aspirar à sabedoria divina, ainda assim, como espécie, embora isso não se mostre do mesmo modo em todos os indivíduos da espécie, apresenta a aspiração à sabedoria, como um impulso para ser mais do que é. Os homens habitam o reino do meio entre o saber e o não-saber; na realidade, sabem que não são nem sábios como os deuses, nem irracionais como as feras, mas o nem isto nem aquilo não é isto nem aquilo, mas um terceiro.

Em Aristóteles se evidenciaria a relação entre a racionalidade e o uso das mãos, mas a substância dessa relação não é estabelecida definitivamente; talvez o ser humano não seja o ser mais compreensivo porque possui mãos, mas possua mãos por ser o ser mais compreensivo. De todo modo, o corpo se integra ao propriamente humano; o andar ereto é compreendido como uma condição, poder-se-ia dizer, uma expressão do desejo de ser mais, quem sabe, para poder pensar; e só os homens são capazes de transmitirem uns aos outros tudo o que querem. Não só Aristóteles, muitos outros viriam a concordar com ele, que o que torna humano os homens não é respirar pelo nariz e a boca, ou comer com as mãos, mas o fato de serem racionais - zóon lógòn, ou seja, de apresentarem linguagem mais desenvolvida do que os outros seres. Por outro lado, para Aristóteles também, além de zóon lógòn, o homem é por natureza um animal político: politikòn zóon. Portanto, na visão que inspira as primeiras definições clássicas de homem são associados estes dois aspectos acentuados: o ser humano é um ser de linguagem complexa, que por ela expressa uma capacidade de pensar superior aos outros seres, por outro lado, esta linguagem manifesta-os como seres de relação, que se estabelecem em relações sociais e da ordem da ação, do poder, da lei, essenciais para sobreviverem em suas casas coletivas, ou seja, nas suas organizações políticas, as cidades.

Na visão clássica do ser humano, pode-se dizer que ele alia o mortal ao imortal. Plantas e animais se referem e submetem aos homens. Na pretensão de manter clara a diferença entre homens e animais, afirma-se que os animais inferiores aos homens emitem apenas sons, que não chega a ser comunicação; os animais possuem voz, mas não propriamente língua, fenômeno que se reserva para a linguagem humana. A razão humana é infinitamente maior e multifacetada, diferente dos animais, e superior. O clássico ideal de humanitas, vivo nas visões filosóficas da Roma antiga, contém e mantém tais conviçcões através dos tempos. O homem é o único ser que tem sentido de ordem e medida; é sensível à beleza, à amabilidade e harmonia das partes; só o ser humano é capaz de planejar e antecipar ações e, assim, configurar sua própria vida de acordo com a razão, sendo a racionalidade comum aos homens e aos deuses.

$\mathrm{Na}$ outra vertente que constitui a cultura ocidental, os textos bíblicos, no Antigo Testamento, em última instância, determinam o homem em sua relação ao Deus único. Ao contrário dos deuses gregos que, com os homens, fazem parte do cosmos, no sentido bíblico, Deus se apresenta ante o homem e o cosmos como seu Criador, como quem age neles e através deles. A história é o lugar no qual Deus e o homem se encontram e dialogam; o homem faz a experiência de si mesmo como alguém que é sempre chamado por Deus e a Ele responde. A velha língua hebraica chama o homem com o nome de Adam que, se em seu primeiro sentido pode significar ser feito de terra, indicaria também a criatura feita à imagem de Deus, que dominará sobre animais e plantas. O homem deve sua vida ao ato livre de criação divina, sem a qual afunda no pó. Que no homem um elemento material se ligue com um elemento espiritual não deve ser compreendido como o mesmo que o dualismo grego, de corpo e alma, pois a Bíblia no Antigo Testamento compreende o homem como ser não só composto, mas complexo, ao mesmo tempo uno e diverso, sob os vários aspectos que indicam o homem todo. De um lado, o homem é descrito no seu aspecto carne, da fraqueza humana, de sua existência provisória e sujeição ao pecado, mas também é reconhecido o aspecto do homem como dotado por Deus com força vital e sabedoria, com atitude e vontade. No Novo Testamento, o modo de ver o ser humano é marcado pela humanização de Deus em Jesus Cristo. Ao mesmo tempo, o ser humano se encontra ante a escolha de pertencer à luz ou à sombra, entre querer ser de Deus ou do mundo. Ao contrário da visão platônica, que vê o corpo como servo da alma, aqui se trata da transformação de todo o homem, inclusive o seu corpo, no modo de ser espiritual. 
As principais correntes antropológicas que, na história da cultura ocidental, buscam compreender o ser humano, têm raízes no pensamento antigo, na filosofia grega e na Bíblia. Antigos, judeus e cristianismo apresentaram o essencial das determinações do homem que a filosofia utiliza até hoje. As fórmulas antigas são utilizadas através dos séculos até a atualidade: o homem é o zòon logòn, animal racional, homo sapiens.

Por muito tempo o ser humano foi considerado como ser especialmente diferente e que se encontra acima de todos os outros seres vivos, por ser o único capaz de pensamento, entendimento, raciocínio, consciência, espírito. A valoração da capacidade de pensar ou da atividade de pensar é a medida para a avaliação do homem, sendo que, na fé da Bíblia, o espiritual transcende o racional, além do que, o homem foi criado por Deus à sua imagem. Mesmo com suas nuances, na compreensão da fronteira entre as partes da alma ou as partes do espírito, da Antiguidade à época moderna, o ser humano é visivelmente compreendido como um ser feito para pensar, e esta pareceu às vezes ser "toda a sua dignidade". Não obstante, também permaneceu até os tempos modernos a concepção do ser humano como um ser de natureza dupla. Desde Platão, afirmou-se e se manteve viva a compreensão do ser humano como um "ser duplo", meio deus, meio animal. Carregando o destino desta sua natureza dupla, o homem precisa harmonizar aspectos contraditórios: mortalidade e imortalidade, corpo e alma, matéria e espírito, matéria e forma, temporalidade e eternidade, dinâmica dos instintos ou impulsos, e domínio da razão.

Os autores medievais, no longo período que pôde chamar-se de época da filosofia cristã, acentuaram a semelhança do homem com a imagem divina, pela sua capacidade de compreensão e de livre arbítrio, embora reconhecessem os limites das duas naturezas do ser humano: corpo e espírito. Também para os primeiros grandes pensadores modernos, se há uma união substancial de alma e corpo, os dois elementos se distinguem claramente, reservando-se a denominação de alma para a razão; somos compostos de duas naturezas opostas e de gênero diverso, de alma e de corpo. E ainda no pensamento central da filosofia crítica alemã o homem seria um ser que pertence a dois mundos, o dos sentidos e o inteligível. É graças a essa duplicidade de natureza, própria do humano, que se apresenta o problema ético, pois o homem tem liberdade e poder sobre si mesmo.

Tão antiga quanto a do dualismo alma e corpo, tem-se feito presente também como uma tradição a do conceito de microcosmo: o ser humano que, por sua natureza complexa, participa em todas as camadas do ser, abaixo e acima dele, por isso representa o mundo em sua totalidade, em seu conjunto, e constrói com ele uma unidade; é, portanto, uma espécie de universo em resumo, o microcosmo dentro do macrocosmo. A fórmula do macrocosmo ante o microcosmo renova a velha doutrina de que o homem contém em si todos os elementos, formas de vida e de ser, ordens ou jurisdições do mundo.

No humanismo da Renascença, como no Iluminismo do século XVIII, o homem foi compreendido menos como determinado pela natureza ou pela vontade divina, mais como ser livre, potente, criador de si mesmo. É quando aparece um ideal de humanidade ou de humanização, que podemos considerar como um ideal moderno. A humanização começa a ser entendida como algo que se busca e se pretende alcançar, para o qual se deve evoluir. Para os primeiros humanistas que valorizaram a liberdade humana, o homem deveria ser seu próprio chefe de obra e escultor, e assim, formar-se ele mesmo da matéria que lhe é própria. A natureza humana deveria desenvolver-se e realizar-se; e o ser humano não deve descansar antes de atingir seu objetivo, que é a humanidade. No modo de ver dos modernos, iluministas e idealistas, a realização da humanidade ou humanização não era apenas um ideal individual, mas uma finalidade, uma meta, que só pode ser atingida pela espécie humana como um todo, no caminho de uma educação integral da espécie, de acordo com a concepção divina. Para os iluministas em geral, a humanidade decorre da perfectibilidade humana e é, portanto, tarefa para a educação, quer dizer, a tarefa da educação. Afirma-se fortemente o ideal de aperfeiçoamento, em conexão com a convicção de que o homem é capaz de mudar para 
melhor. A afirmação da capacidade humana de realização, bem como a força de autodomínio e a capacidade de definir a si mesmo suas próprias metas, são as convicções que dão forma ao humanismo moderno, da Renascença às Luzes, e marcarão a antropologia como sua aplicação à pedagogia.

A meta de aperfeiçoamento não se refere apenas à realização individual, mas à humanidade toda. Para os pensadores da época da Revolução Francesa, parece evidente que o todo vale mais que a parte, mesmo a mais excelente, e que a humanidade inteira vale mais que o melhor dos homens. Através da arte e da ciência, deve-se cultivar, civilizar, moralizar, e isto não se refere apenas ao indivíduo, mas à humanidade, que é suporte do progresso. Esta ideia já havia aparecido antes, no pensamento inglês do século XVI e XVII, quando se lembrava a tarefa de criação do ser humano, que deve continuar a criação operada por Deus. Como na maioria dos modernos, que defenderam a ideia de progresso, já então se afirmou o aperfeiçoamento e a melhoria das condições humanas na expansão do domínio do homem sobre a natureza, apoiado na arte, na ciência e nas invenções mecânicas, concepção que ainda hoje constitui a base da dinâmica do mundo, tão determinado pela ciência e a tecnologia.

Porém, enquanto a maioria dos iluministas ligava o progresso à plena realização da felicidade e dos bens morais do homem, a necessidade desta relação seria posta em questão por outros pensadores do seu século, sobretudo, por Jean-Jacques Rousseau, para quem não seria conciliável o progresso, no sentido do desenvolvimento industrial que entrava em marcha, com a virtude e a felicidade humanas. Embora também mantivesse a meta da humanização pela educação e a da reorganização política, Rousseau apresentava posição menos otimista com relação à civilização burguesa do que a maioria dos seus contemporâneos, sendo mesmo que, para ele, na medida em que as ciências e as artes progridem, as almas dos homens se corrompem. A posição de Rousseau está na origem de todas as ciências humanas que tomam distância crítica em relação à sociedade burguesa e industrial.

Ao mesmo tempo próximas e distintas, as concepções de Rousseau e as de Kant parecem complementar-se. Os objetivos da humanidade, para Kant, não são a felicidade do indivíduo nem uma futura época de ouro, mas realizar uma constituição estatal e política completa, no seu sentido intrínseco e extrínseco, como condição na qual a natureza possa desenvolver inteiramente todas as suas bases na humanidade. A humanidade está longe da realização moral plena, e muito longe do que deve ser buscado através de reformas graduais dos costumes; por isso, para o indivíduo exige-se uma revolução de orientação, uma espécie de ressurreição, também possível para a humanidade como um todo, esperança próxima da de um povo de Deus sob leis éticas. Esta obra, em última análise, não será feita pela humanidade, e só se pode esperar seja realizada por Deus.

Caminhando para a era contemporânea, contudo ainda integrados ao espírito próprio do esclarecimento moderno e humanista, outros filósofos afirmaram outro sentido de logos, que passa a ser explorado para além de sua significação de pensamento, como linguagem, que não esquece sua encarnação no sentimento e na sensibilidade. Herder afirmaria que o homem se diferencia dos outros animais porque é a única criatura capaz de falar; a linguagem é o caráter de nossa razão. E para Humboldt o homem só é humano através da fala, da linguagem; mesmo se, paradoxalmente, para descobrir e desenvolver a linguagem, já precisava ser humano. A linguagem e o pensamento são identificados como as características próprias do ser humano.

O ideal moderno de humanidade aponta consequências para a educação e a cultura, e no tempo do romantismo, o ideal de humanização aparecia como um objetivo alcançável por cada indivíduo. A humanidade é o livre exercício das mais nobres forças espirituais, a livre e razoável autonomia. E enquanto se mantém a consciência da tensão entre os dois elementos constitutivos do ser humano, ou seja, dos diversos aspectos do homem, afirma-se também o homem como um todo. A convicção tradicional só começa a fraquejar, no século XIX, quando 
a dualidade espírito-matéria pôde ser considerada com realidade apenas na teoria, sendo negada na vida e na práxis, também quando a oposição entre alma e corpo pôde parecer falsa.

O ser humano como parte da natureza foi tema de muitos dos humanistas modernos, desde o renascimento até o iluminismo, e encontrou forte afirmação na época contemporânea, nos séculos XIX e XX. Tal temática uniu os mais diversos, mesmo contrários pensadores, das diversas escolas de pensamento e nacionalidades. Para comprovar essa unidade na diversidade, e aprofundar a questão do pensamento sobre a posição do homem na natureza, seria preciso considerar com mais vagar concepções muito diversas e distanciadas no tempo, até as de Charles Darwin e seus discípulos, o que foge à finalidade deste pequeno texto.

Verdade é que, no século XIX, a imagem do ser humano apareceria sob novos aspectos, ou dito de outro modo, as imagens do homem se diversificaram. Sob a influência de Darwin, manteve-se muito forte no século XX a imagem do homem como produto da evolução, sendo que assim ainda se mantém na atualidade. Darwin e os outros cientistas que desenvolveram as ciências naturais e sobre elas assentaram suas teses antropológicas, acentuaram o parentesco entre todas as criaturas, inclusive o ser humano. Esse parentesco já tinha sido percebido antes deles, por uma linha longa de pensadores que pode ser encontra desde Aristóteles até Goethe; mas a contribuição decisiva dos evolucionistas nos séculos XIX e XX foi encontrar uma nova explicação para o parentesco entre os seres vivos, ao desenvolver a teoria da descendência, que a rigor já aparecia em escritos antigos, mas foi colocada em outro patamar, com as teses das transformações genéticas casuais das formas orgânicas e consequências naturais na luta pela vida, que, ao longo de milhões de anos, teriam levado ao surgimento das espécies mais completas, superiores, originadas das menos completas, inferiores.

A tarefa de uma gradual realização do mundo e da espécie humana, que no começo da modernidade tinha sido transferida de Deus para o próprio homem, foi mais uma vez delegada, agora do ser humano para a natureza. A evolução vê o aparecimento do homem, mas permanece polêmico se este não deve ainda contribuir para a sua realização ou complementação. A maioria da comunidade científica mundial acreditou que Darwin havia conseguido demonstrar que toda a natureza orgânica existente, com isto também a espécie humana, é produto de um processo de desenvolvimento continuado através de milhões de anos. Importantes autores se seguiram a Darwin na teoria da evolução em relação com a realização do homem ou humanização, nos quais se têm, além de ciência, uma percepção poética da natureza, uma visão de mundo e da realidade humana. Uma apresentação da teoria evolucionista sobre o homem que alia à ciência e à dimensão poética ainda a profundidade religiosa e mística, encontra-se no pensamento do pesquisador e padre católico Teilhard de Chardin.

Um dos novos modos que se afirma na concepção antropológica contemporânea é a do homem como ser de vontade e impulso. Além das ciências naturais, o marxismo e também a psicanálise contribuiriam para o questionamento do idealismo, da visão clássica do homem como ser racional e político. Utilizando-se de premissas e elementos destas duas correntes do pensamento ocidental na passagem da modernidade à época contemporânea, os pensadores da teoria crítica, da chamada Escola de Frankfurt, constituem uma referência importante. Ideológica e politicamente próximo à Escola de Frankfurt, mas dela se distanciando, entre os exemplos da contribuição do pensamento crítico para a questão do ser humano, lembramos mais uma vez a concepção antropológica de Ernst Bloch (1885-1977), do homem como ser em possibilidade.

Já tive ocasião de apresentar o modo de Ernst Bloch entender o ser humano como primeiramente um ser de pulsões. Coerente com a estrutura ontológica do ser como ainda não ser, o ser que é ainda não ser se mostra no ser humano em suas carências expressas nos desejos e tendências, que são indicações de possibilidades reais, subjetivo-objetivas, e pressionam no sentido de sua realização. Situados em corpos individuais, o impulso primeiro dos seres 
humanos, que expressa sua carência, portanto, sua possibilidade de realização, é a fome. $\mathrm{O}$ impulso básico dos homens é a fome e em primeiro lugar a fome material, a fome de alimento; contudo, as fomes dos homens são numerosas e variadas, embora se enraízem todas em uma base material: a fome do amor, de substância afetiva e pessoal, é ancorada no corpo; a fome de prazer estético, que tem dimensão de nível espiritual, é ancorada no sentido da visão ou da audição, particularmente, apoia-se no ouvido, quando se trata da música, à qual volta sempre a reflexão de Bloch, desde sua primeira grande obra, Espírito da utopia. O amor como a arte são momentos de realização da utopia, do ser possível verdadeiro do humano.

A antropologia filosófica contida nos textos do filósofo da utopia desenvolve, de modo sofisticado, inspirado, barroco, o que aqui resumimos como sendo a afirmação de um ser de impulsos que pressionam em direção de sua satisfação. Ao ser humano não é negado o movimento e a brecha da liberdade, tal como o fazem os determinismos biológicos ou sociais; contudo, também não é negado nem esquecido o elo íntimo do espírito com a matéria, a vida, a carne, base que comanda a aparição da pulsão, do instinto, do desejo, da aspiração. Os textos de Bloch pensam as diversas fomes humanas, as do corpo como as do afeto, as do conhecimento como as do espírito. Tais fomes múltiplas, que se apresentam em tão vários níveis e em relação a objetos de substância tão diversa, mostram reais carências dos seres humanos, sintomas de suas possibilidades ainda não realizadas. Este ainda não ser dos homens, que ainda não é, mas pode vir a ser, manifesta-se pela imaginação humana, na consciência antecipadora, nos sonhos da humanidade. As diversas carências e possibilidades dos homens se revelam em seus sonhos. Uma das primeiras distinções estabelecidas por Bloch na análise dos fenômenos contidos na imaginação humana é a distinção entre sonhos noturnos e devaneios diurnos. Se os sonhos noturnos, de acordo com a afirmação de Sigmund Freud (1856-1939), põem em cena a realização de desejos e remetem ao passado, ao já não consciente, os diurnos, ao contrário, os sonhos acordados, devaneios feitos no estado de vigília, elaboram o ainda não consciente e se orientam para as possibilidades do futuro, que aparecem diretamente em imagens, sem a mediação do símbolo. Os sonhos diurnos se diferenciam entre eles, apresentando uma infinita graduação, da imprecisão até a claridade, da imaturidade até a maturidade; contudo, a utopia, a terra da felicidade que se busca no mundo dos sonhos acordados, embora de modo fragmentário, realiza-se pelas obras de arte, sobretudo, pela música.

\section{Dúvidas que permanecem}

Para responder à pergunta prática, em que medida e em que sentido o novo tempo livre pode servir à meta humanista, de humanização, precisamos enfrentar as dúvidas conceituais, que se fazem presentes ainda no meio dos estudiosos que falam do humano. A dúvida sobre o que é o ser humano, e o que é o humano no homem, permanece no centro do debate acadêmico, bastando, para esta convicção, acompanhar o balanço realizado em certo cenário da academia na França da atualidade. O vocábulo humano e seus relativos, tais como desumano, subumano, sobre-humano, ainda animam a polêmica nas ciências humanas, bem como em outros domínios das humanidades e, num e noutro desses espaços, o debate assume diferentes conotações. De todo modo, no século XX houve bons intelectuais e filósofos prontos a profetizar a morte da visão tradicional do homem como um ser racional, de um lado, e como um ser político, de outro, ou seja, a morte do homem, segundo as clássicas definições aristotélicas que se estabeleceram na cultura científico-filosófica ocidental.

Têm contribuído para essa nova perplexidade e ceticismo sobre o humano e as possibilidades superiores da humanidade, tanto a ciência da evolução no plano das ciências naturais e biológicas, como as vivências traumáticas do poder de violência e barbárie, que 
marcaram a história dos últimos cem anos e continuam assombrando os espíritos neste começo do século XXI. Atingido pelas teorias contestadoras do século da ciência ou era das revoluções, e pelas trágicas vivências da era dos extremos, o humanismo foi posto sob suspeita, dando lugar ao anti-humanismo, de tal modo que alguns chegam a considerar o sonho humanista como coisa do passado, quem sabe mesmo, sem razão de ser.

Parece-me sensato, no entanto, manter o pressuposto de que, reconhecido que o ser humano é capaz tanto do mal como do bem, de destruição como de construção, da barbárie como da cultura, de desrazão como de razão, o ideal de si mesmo, ideia que se havia construído sobre si mesmo como possibilidade, na consciência de ser enquanto espécie capaz de aperfeiçoamento, ideal humano, continua válido, e está posto aí para ser dinamicamente repensado, funcionando como ideia reguladora, como um postulado, quem sabe, uma utopia positiva, relevante do ponto de vista antropológico, para o plano prático da vida social e política, como referência ética, muito especialmente importante para os que se dedicam à obra da educação.

As vicissitudes do conceito de humanização, como vimos no resumo de sua história, têm sido muitas; não há como preencher as lacunas do conceito sem reabrir o debate e a reflexão sobre o que parece ter desaparecido ou está ao mesmo tempo em mudança e em questão. A humanidade como espécie compreende-se como resultado de um processo duplo, de hominização e de humanização. A expressão hominização indica um longo processo biológico de evolução pelo qual a espécie humana se constituiu, separando-se progressivamente das espécies das quais se teria originado: classe dos mamíferos, ordem dos primatas, quer dizer, de acordo com a teoria evolucionista, é o tornar-se homem de uma linhagem de primatas no seio da evolução, dando origem ao homo sapiens dentro do reino animal. Por outro lado, humanização é para ser compreendido como tornar-se humano, como o avanço no plano da formação e da cultura, o que vale tanto para a espécie como para o indivíduo.

Hominização e humanização têm em comum o ser de fato, no sentido descritivo e para toda a espécie, o resultado de um processo, mas só a humanização pode pretender um sentido normativo, uma qualificação de valor. A humanização tem a ver com a questão da educação de um indivíduo; educar uma criança pode mesmo ser dito como instituir nela a humanidade; educar é crescer em humanidade, fazer crescer em si o caráter de ser humano. $\mathrm{O}$ humano, portanto, é objeto não somente de uma evolução, mas de um devir, e o ser humano participa deste devir. A humanidade de fato herda e participa de um processo em devir, de hominização e de humanização, que atinge o plano da noção de valores e nos instrui sobre o que se pode classificar de humano.

Há uma ordem do humano no todo do real, no seio do universo, diferente das outras ordens, irredutível às classificações biológicas ou físicas; mas a distinção entre os reinos mineral, vegetal e animal, ao qual também pertence o homem, não esclarece sobre o propriamente humano, sobre aquilo que é próprio da humanidade, sobre aquele algo que só pode ser determinado a partir da humanidade. Por tudo isso, ressalta a posição que vê como o mais marcante e próprio do ser humano o fato de ser incompleto e, de certo modo, não realizado.

Na coletânea publicada por Francis Affergan em 2003, o antropólogo italiano Francesco Remotti centraliza sua reflexão sobre o fato da incompletude, vista como traço fundamental do fenômeno humano. $\mathrm{O}$ autor faz a ligação entre a incompletude humana e a capacidade de o ser humano construir-se e inventar-se, a antropo-poiesis, o que pode, ainda, ser posto de três modos: ou a incompletude é estabelecida como um dado básico, fundamental, que suscita as operações antropo-poiéticas; ou, de modo diferente, estas deveriam fixar-se objetivos de realização que indicariam uma completude; ou seria presumida uma completude de fundo, que tornaria supérflua, vã e ilusória a empresa antropo-poiética.

A ideia do homem como incompletude e abertura para a autoconstrução sem previsão de acabamento, é também, em outros termos, a posição de Ernst Bloch, que apresenta o 
universo, o todo existente, e não só o homem, como um ser em aberto, não inteiramente determinado e, assim, marcado pela abertura para o novo, sendo o homem de modo específico um ser em possibilidade; portanto, o humano, a rigor, não é de todo conhecido, não acabamos de ver o que ele é, porque ainda não vemos tudo do que ele é capaz. O homem é um ser que nasce prematuro, mas não só isto, para Bloch, o ser humano é um ser que morre prematuro. Esta me parece ser uma maneira expressiva de acentuar a incompletude como dado substancial da condição humana: o ser humano se caracteriza como ser em possibilidade, em expectativa, e imaturo; o ser humano é um ser prematuro enquanto espécie. Isso é o que se revela no modo de ser do humano como ser de pulsões, de latências que se põem em tensão e em atividade até que se definem em tendência.

Ainda assim, e talvez por isso mesmo, a pergunta não parece ter sido bem respondida: como entender o que se diz com humano e desumano, subumano, sobre-humano? Seria talvez somente detectável pelo estudo dos fenômenos produzidos sobre, ou em redor do homem, pela ação humana, nas próprias ciências humanas? O humano seria o que se encontra ao analisar os fenômenos do plano da espécie humana? Então teríamos um círculo perfeitamente fechado? Para alguns dos intelectuais que pensaram a questão, é como se esse quid da natureza do homem, e a sua medida, pudesse aparecer apenas na sombra do conceito, quando se tenta dizer o seu oposto; ou seja, apareceria pelo paradoxo, pela contradição, quando algo se percebe como desumano, subumano, ou mesmo, sobre-humano; mas a rigor, o "humano" é algo incompleto, portanto, ainda não é inteiramente conhecido enquanto tal.

Entre o animalesco e o divino, o homem busca seu ser próprio. O ser humano pode ser dito como ponte entre o natural e o cultural; não bem a clássica natureza dupla, de corpo e alma, entre o animal e o divino, mas, na linguagem desencantada dos contemporâneos, o humano é a ponte entre a natureza e a cultura. O humano se refere ao conjunto do real feito pelo homem, que concerne a ele, e é também aquilo do qual os humanos são capazes, por isso, é o ainda não existente, o possível desejado, ainda não realizado.

\section{O tempo livre, a cultura e a arte, na filosofia da utopia}

O filósofo que levou os sonhos a sério, Ernst Bloch, ao final de sua enciclopédia das utopias, escreveu sobre o tempo livre, pensando-o ao mesmo tempo como ocorre na realidade e como tende a tornar-se, na clave da possibilidade revelada pela esperança e a imaginação humana. No grande livro O princípio esperança, dentro do capítulo intitulado "Jornada de oito horas, mundo em paz, tempo livre e lazer", desenvolve-se a crítica ao que é, no capitalismo desenvolvido, o "tempo livre" possibilitado pela diminuição do trabalho de produção material. A reflexão do capítulo começa pela crítica do pacifismo irrefletido. "Paz é igual a luta e desigual a guerra" foi em síntese o conteúdo do discurso de Ernst Bloch em Frankfurt, em 1967. O discurso na Igreja de São Paulo em Frankfurt, ao receber o Prêmio da Paz concedido pelos livreiros alemães, sintetiza bem o pensamento do filósofo de Tübingen sobre a violência e a paz, em sua relação com a utopia. $O$ pacifismo do otimismo militante exige resistência, a autêntica paz social requer e exige a luta, e esta indica, finalmente, a possibilidade de superação da guerra. As lutas de libertação, por estarem associadas a um conteúdo utópico que, de certo modo, as justifica, têm outro conteúdo ético e não podem ser confundidas com as guerras de dominação. No referido capítulo de O princípio esperança, faz-se sentir um tom irônico sobre "a paz dos cemitérios", que encobre a conivência e a covardia, o que aconteceu no "momento obscuro do presente", que é aquele tempo da elaboração da indignação, do luto e da decepção ligados à experiência coletiva do holocausto na barbárie nazista. 
Depois do ensaio sobre a paz, o filósofo da esperança se permite desenvolver sua reflexão sobre o tempo livre, sua realidade histórica e seu sentido de novo, dimensão de oportunidade, no plano da possibilidade. Bloch começa por fazer a crítica ao tempo livre após o trabalho, que se segue à jornada de produção, ilusão que teria a função socioeconômica de preparar o trabalhador para servir à empresa. O desencanto e a desorientação se imiscuem no escasso tempo de descanso das máquinas, as condições ambientais só permitem o precário refazer das forças, de modo a continuar-se exercendo a produção alienada na engrenagem da indústria. Uma variante do tempo livre no fim de semana das cidades contemporâneas é a do lazer pequeno-burguês que se expressa de modo patético no tédio azul-cinza tal como pintado no quadro Um domingo na Grande-Jatte, de Seurat, que o filósofo descreve como "retrato de um recreio aguado-desesperado" (Bloch, 2006, p. 461).

No fragmento em destaque, o consumo de bens culturais é pensado com distanciamento: "há um esforço de transformar Mozart em caramelo, Goethe em filisteu, a Nona Sinfonia em uma pregação dominical sem cor denominacional” (Bloch, 2006, p. 463). A reflexão blochiana neste ponto apresenta afinidade com a crítica da indústria cultural que aparece nas publicações da Escola de Frankfurt. Coerente com seu sistema da esperança e do otimismo militante, todavia, Bloch reconhece as sementes de utopia na realidade do tempo livre e do lazer - o "que não foi pervertido: o hobby, a festa popular, o anfiteatro para todos", e considera a existência de autêntica e fecunda substância de possíveis novidades nas "formas remanescentes mais antigas do tempo livre, deturpadas, porém não sem esperança" (Bloch, 2006, p. 459). A simpatia do filósofo se dirige para as possibilidades abertas pela festa popular com exuberante folclore, pela herança da festa popular, sobretudo nos países de tradição católica, o que parece tornar plausível o adjetivo "catolicizante" que às vezes lhe foi atribuído. Assim, se Bloch (2006) acusa as deturpações da cultura, demonstrando afinidade com a teoria crítica da Escola de Frankfurt, não deixa também de notar que

sempre existe ainda uma parcela humana que não foi vendida ou não foi vendida integralmente, esta é igualmente a mesma que ainda não se tornou livre para si própria. Por essa razão, busca sua alforria não por último no lazer. Por consequência, a cultura forma, no lazer que é seu trabalho, em lugar das ilusões das horas após o trabalho, substâncias do verdadeiro tempo livre. Porque não há nada mais ameaçado e esperançoso que isso, nada precisa de mais cultivo que essa área humana, ainda insuficientemente humana (p. 466).

Entre os lazeres modernos, Bloch distingue os que estão preparados pelo sistema capitalista e comercial e servem para manter a inconsciência e a submissão, dos que realmente podem desenvolver nos homens aquele "melhor" apenas intuído, no qual eles podem se transformar. No plano destes lazeres, em que é transmitida a mensagem sutil e discreta da felicidade possível, embora fragmentária e provisória, antecipamos pelo sentimento e pela intuição o mundo melhor. E se a felicidade se encontra naquele mundo sonhado, o mesmo que é buscado pela concreta luta política e que, até certo ponto, como já dissemos, encontra sua realização nas grandes obras de arte como nas sinfonias de Beethoven - sendo o que acontece

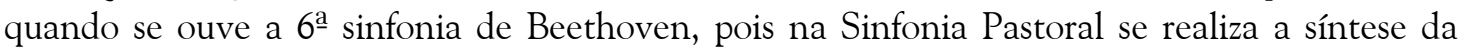
"natureza humanizada" e do "homem naturalizado", então, parece certo deduzir: quando a finalidade, o desejo, é o aperfeiçoamento humano, a humanização, então, deve-se buscar a cultura e a arte.

Por isso o trabalho dos profissionais da cultura - dos escritores, artistas plásticos, dramaturgos e atores, muito especialmente, dos músicos, mais toda a gama de novos produtores culturais que surgiram em nosso tempo do cinema e demais meios de comunicação de massa -, são os responsáveis por elaborar o conteúdo da nova esperança de humanização, do esforço de superação da cultura vendida e vulgarizada ao plano do consumo comercial. A transfiguração da cultura comercial, do lazer deturpado da indústria cultural em cultura autêntica, orientada 
no sentido da humanização, da elevação não piegas nem ingênua, para o plano próprio aos adágios das sonatas de Beethoven, aos prelúdios e fugas de Bach, às valsinhas de Nazareth, às pinturas de Rembrandt, Van Gogh ou Marc Chagall, às páginas dos Irmãos Karamazov de Dostoievski ou de Em busca do tempo perdido de Proust, sem que isso seja apenas reprodução que dê lucro às empresas gravadoras e museus; esta é a tarefa problemática que desafia os educadores e homens de cultura de hoje.

Em alguns de seus ensaios, Bloch afirmou a distinção e a relação dialética entre ideologia e utopia, distinção presente na realidade da arte como na das obras de cultura. Essa diferença, portanto, aquela transformação cultural e artística que o humanismo pretende, tira seu caráter do elemento utópico, ou seja, refere-se à antecipação da sociedade sonhada de liberdade e igualdade, de felicidade e justiça. $O$ filósofo da utopia fazia distinção entre as obras de arte de valor utópico e as de sentido ideológico, mas isso em seu pensamento não tinha um sentido estreito, de modo que a boa obra de arte seria reconhecida como tal mesmo que se houvesse tornado remanescente de uma cultura em decadência. A arte do passado, ou aquela situada em nossa época que expressa uma situação histórica contraditória que se deseja superar, também reclamam o reconhecimento como arte autêntica. É em uma associação ao mesmo tempo complexa e sutil que se entretece a ligação entre a obra de arte e a cultura com a vida dos homens de seu tempo e sua humanização, pela cultura que pode vir a ser ao mesmo tempo erudita e popular, elevar-se ao nível da arte universal enquanto expressa um povo, e assim revela sua potência ao mesmo tempo em que antecipa aquele ser algo mais e melhor, sonhado, da humanidade. O verdadeiro lazer viverá "desse conteúdo sempre esperado, em boa hora atualizado, de sermos nós mesmos, ou de liberdade, em um mundo igualmente não-alienado. Somente num mundo assim o homem se sentirá em casa" (Bloch, 2006, p. 477).

Bloch elaborava sua reflexão sobre a cultura e a arte no plano da interpretação da história: no período de afirmação de uma classe social, as obras de cultura contêm elementos ideológicos associados aos seus elementos utópicos, em prol da mudança histórica, que o movimento da criação cultural e artística acompanha; passado o seu momento inovador, entretanto, tomarão um certo sentido ideológico; mas nelas permanece algo que não se deixa conter totalmente dentro do conceito de ideologia, pois as obras de arte, que costumam ser inclusive mais pródigas e ricas nos momentos de apogeu de uma forma de sociedade, não perdem totalmente o seu valor como obras de arte, expressivas do humano; nem perdem os seus conteúdos utópicos, nem mesmo no período da decadência daquela sociedade.

Os homens sonharam por muito tempo com a terra da liberdade onde desapareceriam os trabalhos mais duros, com a Schlaraffenland onde os alimentos cairiam das árvores diretamente sobre as bocas esfomeadas. Inúmeras formas de relato e sonho reapresentaram o Jardim das delícias, do Éden, onde não se conhece o trabalho e o excesso de esforço físico. Os sonhos humanos têm força de realidade e, segundo o pensamento da esperança, podem transformar o mundo, por isso importa pensar sobre a Pasárgada imortal evocada por Manuel Bandeira, e a promessa contida no sonho do país liberto das penas do trabalho. A redução do tempo de trabalho e as novas possibilidades de tempo livre e lazer aproximam a humanidade do que sonharam as utopias. Por isso é paradoxal que aos contemporâneos só apareçam sob seu ângulo mais negativo. De outro lado, a aspiração a um mundo mais humano, onde não se destruam tantas energias na produção material, onde se possa dedicar mais tempo ao prazer de ouvir as harmonias da música de Mozart, Debussy ou Villa-Lobos, ou para continuar sua obra em novas composições e, assim, ser feliz e ser mais humano, mesmo se parece utopia, não é para ser tida como fora de propósito, como fora de interesse, pois as utopias com fundamento no real e sonhadas por muitos tendem à realização.

Por que não olhar com esperança o aumento do tempo livre, que as novas tecnologias possibilitam? Por que não compreender a expansão do tempo livre do trabalho como promessa de mais tempo para o descanso, para o convívio familiar, para o apoio do outro, para o cultivo da amizade? Como condição para a continuação do desenvolvimento da informação, da 
comunicação, da educação? Como condição de acesso às atividades físicas e aos esportes, desenvolvimento cheio de promessa de mais saúde? Como promessa de melhor convívio com as obras de cultura e as artes? Como oportunidade para a atuação comunitária? Oportunidade para a ação política? Convite para o cultivo da filosofia? Convite para as práticas espirituais? Logo, como promessa, oportunidade, condição, convite para aperfeiçoamento e progresso, no sentido mais clássico e integral de humanização?

\section{Referências}

Affergan, F. et al. (2003). Figures de l'humain. Paris: Editions de l'EHESS.

Albornoz, S. G. (2006). Ética e utopia: ensaio sobre Ernst Bloch (2 $\underline{\text { a }}$ ed.). Porto Alegre/Santa Cruz do Sul: Movimento/Edunisc.

Bloch, E. (2006). O princípio esperança. Rio de Janeiro: Contraponto.

Bloch, E. (1967). O homem como ser em possibilidade. Revista Tempo Brasileiro, Rio de Janeiro.

Go, N. (2004). L'humain. Le Philosophoire, 23, 51-62.

Hügli, A. et al. (1980). Mensch. In J. Ritter et al. (Eds.), Historisches Wörterbuch der Philosophie (vol. 5, pp. 1059. 1105). Darmstadt: WBG.

Remotti, F. (2003). De l'incomplétude. In F. Affergan et al. (Eds.), Figures de l'humain. Paris: Editions de l'EHESS.

Ritter, J. et al. (1980). Historisches wörterbuch der philosophie (vol. 5). Darmstadt: WBG.

\section{Endereço para correspondência}

suzanaalb@viavale.com.br

Recebido em: 03/11/2008

Aprovado em: 24/04/2009 